\title{
First isolation of the pan-azole-resistant Aspergillus fumigatus cyp51A TR46/Y121F/T289A mutant in a UK patient
}

DOI:

10.1016/j.ijantimicag.2017.01.004

\section{Document Version}

Accepted author manuscript

Link to publication record in Manchester Research Explorer

Citation for published version (APA):

Moore, C., Novak-Frazer, L., Muldoon, E., Dunn, K. W., Masania, R., Richardson, M., \& Richardson, R. (2017). First isolation of the pan-azole-resistant Aspergillus fumigatus cyp51A TR46/Y121F/T289A mutant in a UK patient. International Journal of Antimicrobial Agents. https://doi.org/10.1016/j.ijantimicag.2017.01.004

\section{Published in:}

International Journal of Antimicrobial Agents

\section{Citing this paper}

Please note that where the full-text provided on Manchester Research Explorer is the Author Accepted Manuscript or Proof version this may differ from the final Published version. If citing, it is advised that you check and use the publisher's definitive version.

\section{General rights}

Copyright and moral rights for the publications made accessible in the Research Explorer are retained by the authors and/or other copyright owners and it is a condition of accessing publications that users recognise and abide by the legal requirements associated with these rights.

\section{Takedown policy}

If you believe that this document breaches copyright please refer to the University of Manchester's Takedown Procedures [http://man.ac.uk/04Y6Bo] or contact uml.scholarlycommunications@manchester.ac.uk providing relevant details, so we can investigate your claim.

\section{OPEN ACCESS}




\section{Accepted Manuscript}

Title: First isolation of the pan-azole-resistant Aspergillus fumigatus cyp51A TR46/Y121F/T289A mutant in a UK patient

Author: Caroline B. Moore, Lily Novak-Frazer, Eavan Muldoon, Kenneth W. Dunn, Rikesh Masania, Malcolm D. Richardson, Riina Rautemaa-Richardson

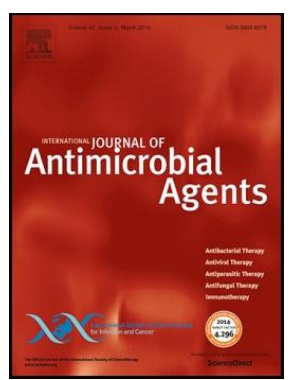

PII:

DOI:

S0924-8579(17)30041-9

Reference: http://dx.doi.org/doi: 10.1016/j.ijantimicag.2017.01.004

To appear in: ANTAGE 5024

Received date:

International Journal of Antimicrobial Agents

Accepted date:

10-11-2016

28-1-2017

Please cite this article as: Caroline B. Moore, Lily Novak-Frazer, Eavan Muldoon, Kenneth W. Dunn, Rikesh Masania, Malcolm D. Richardson, Riina Rautemaa-Richardson, First isolation of the pan-azole-resistant Aspergillus fumigatus cyp51A TR46/Y121F/T289A mutant in a UK patient, International Journal of Antimicrobial Agents (2017), http://dx.doi.org/doi: 10.1016/j.ijantimicag.2017.01.004.

This is a PDF file of an unedited manuscript that has been accepted for publication. As a service to our customers we are providing this early version of the manuscript. The manuscript will undergo copyediting, typesetting, and review of the resulting proof before it is published in its final form. Please note that during the production process errors may be discovered which could affect the content, and all legal disclaimers that apply to the journal pertain. 


\section{First isolation of the pan-azole-resistant Aspergillus fumigatus cyp51A TR46/Y121F/T289A mutant in a UK patient}

Sir,

Antifungal resistance in Aspergillus fumigatus owing to a number of mutations has been reported from many regions of the globe. The cyp51A gene

TR46/Y121F/T289A mutation is an emerging mechanism conferring resistance to azole antifungal drugs. It is unclear whether these mutations are acquired from specific ecological niches or are generated by long-term exposure to azoles during suboptimal therapy. Previous surveys of azole resistance in the UK have not found this mutation [1-3].

A man in his early forties was admitted to the Adult Burns Centre of University Hospital of South Manchester (Manchester, UK) in April 2016 following self-inflicted burns involving $44 \%$ of total body surface area. He also had an associated inhalation injury requiring immediate intubation and ventilation. His wounds became colonised with Candida parapsilosis and he was administered fluconazole (Days 34-40) and subsequently transitioned to anidulafungin (Table 1). His hospital course was complicated by bowel ischaemia requiring subtotal colectomy on Day 34 of admission as well as bilateral necrosis of his fingers distally.

On Day 47, A. fumigatus was isolated from a non-directed bronchoalveolar lavage (BAL) specimen. Lung computed tomography (CT) demonstrated large bilateral pleural effusions with associated atelectasis. A directed bronchoscopy was performed but no features suggestive of airway aspergillosis were seen. Abdominal 
complications following bowel ischaemia and surgery were ongoing, requiring further drainage and laparoscopy and washout on Day 83 (Table 1). His ventilator requirements increased in association with this.

On Day 70, Aspergillus flavus was isolated bilaterally from the patient's hands. On abdominal CT performed due to intra-abdominal complications, images from the lung bases demonstrated bilateral dense consolidation. He was commenced on micafungin and liposomal amphotericin $\mathrm{B}(\mathrm{AmB})$ mainly to cover the $A$. flavus from the necrotic areas of his hands. These were stopped on Days 141 and 200, respectively.

The patient was discharged to rehabilitation on Day 228 with no signs of ongoing infection and having discontinued all antifungal agents.

The patient worked in a marble plant where he was involved in resizing imported marble from Spain and Italy. His last travel abroad (Spain) was ca. 3 months prior to admission. He had no history of prior use of azole antifungals.

Respiratory, wound and blood samples were collected regularly from Day 1 onwards (Table 1). Aspergillus fumigatus resistant to itraconazole, voriconazole, posaconazole and isavuconazole [minimum inhibitory concentrations (MICs) of $>8$, $>8,1$ and $>8 \mathrm{mg} / \mathrm{L}$, respectively] was first isolated from a non-directed BAL on Day 47 post-admission. Pan-azole-resistant $A$. fumigatus isolates were also reported from a variety of respiratory samples on Days $53,57,69$ and 74 . All of these isolates 
were susceptible to AmB and echinocandins. Prior to Day 47, twelve respiratory samples taken as part of routine care had been reported negative for fungi.

Weekly environmental monitoring of indoor and outdoor air was performed throughout the patient's admission because of construction work adjacent to the Burns Centre. All A. fumigatus isolates from air samples were susceptible to all azoles, echinocandins and AmB.

Nucleic acids were extracted from the patient isolates taken on Days 47 and 57. Identification of $A$. fumigatus was confirmed by sequencing the internal transcribed spacer (ITS) region as well as $\beta$-tubulin and calmodulin genes. In addition, the entire cyp51A gene, including 360 bases $5^{\prime}$ upstream of the start codon, was amplified by PCR. The amplified gene product was purified and sequencing, revealing a TR46 repeat insertion (TCTAGAATCACGCGGTCCGGATGTGTGCTGAGCCGAATGAAAGTTG) in the 5' region upstream of cyp51A. In addition, the mutations Y121F and T289A were detected. No other mutations were found.

Here we report the first case of a pan-azole-resistant $A$. fumigatus cyp51A TR46/Y121F/T289A mutant in the UK. The source of this isolate is not clear, but it is unlikely that resistance evolved in the patient considering his minimal exposure to azole antifungals during hospitalisation. Although extensive environmental sampling was performed in the Burns Centre and outside, no other similar isolates were identified. It is possible that the patient carried the azole-resistant $A$. fumigatus in his airways prior to admission. However, it is unlikely that it would have remained 
dormant in the airways for 47 days, especially considering how profoundly immunocompromised a patient with $44 \%$ burns and an inhalation injury is. It is even more unlikely that the patient would have carried the $A$. fumigatus conidia in his airways for over 4 months since his last trip abroad. Therefore, it can be assumed that he had obtained the pan-azole-resistant $A$. fumigatus cyp51A TR46/Y121F/T289A mutant from the environment within the UK.

This is of clinical importance because first-line therapy for pulmonary aspergillosis is voriconazole [4] as azole resistance is not acknowledged in treatment-naïve patients. In addition, previous reports have associated the $A$. fumigatus cyp51A TR46/Y121F/T289A mutant with invasive disease and therapy failure [5]. The extent of azole resistance due to this or other mutations is in the UK is impossible to estimate as susceptibility testing is not routinely performed for clinical and environmental mould isolates. Nevertheless, it is likely that this case represents a 'tip of the iceberg' and that there is an environmental origin. We advocate the introduction of UK-wide genetic analysis of azole-resistant isolates of $A$. fumigatus to enable monitoring of environmental transmission.

Funding: None.

Competing interests: None declared.

Ethical approval: Not required. 


\section{References}

[1] Howard SJ, Cerar D, Anderson MJ, Albarrag A, Fisher MC, Pasqualotto AC, et al. Frequency and evolution of azole resistance in Aspergillus fumigatus associated with treatment failure. Emerg Infect Dis 2009;15:1068-76.

[2] van der Linden JWM, Arendrup MC, Warris A, Lagrou K, Pelloux H, Hauser PM, et al. Prospective multicenter international surveillance of azole resistance in Aspergillus fumigatus. Emerg Infect Dis 2015;21:1041-4.

[3] White PL, Posso RB, Barnes RA. Analytical and clinical evaluation of the PathoNostics AsperGenius assay for detection of invasive aspergillosis and resistance to azole antifungal drugs during testing of serum samples. J Clin Microbiol 2015;53:2115-21.

[4] Patterson TF, Thompson GR 3rd, Denning DW, Fishman JA, Hadley S, Herbrecht R, et al. Practice guidelines for the diagnosis and management of aspergillosis: 2016 update by the Infectious Diseases Society of America. Clin Infect Dis 2016;63:e1-60.

[5] Verweij PE, Chowdhary A, Melchers WJG, Meis JF. Azole resistance in Aspergillus fumigatus: can we retain the clinical use of mold-active antifungal azoles? Clin Infect Dis 2016;62:362-8.

Caroline B. Moore ${ }^{a, b, c}$

Lily Novak-Frazer ${ }^{\mathrm{a}, \mathrm{c}}$

Eavan Muldoon ${ }^{b, c}$

Kenneth W. Dunn ${ }^{\text {d }}$

Rikesh Masania $^{a}$

Malcolm D. Richardson a,b,c 
Riina Rautemaa-Richardson ${ }^{\mathrm{a}, \mathrm{b}, \mathrm{c}, *}$

a Mycology Reference Centre Manchester, University Hospital of South Manchester, Manchester, UK

${ }^{\mathrm{b}}$ National Aspergillosis Centre, University Hospital of South Manchester, Manchester, UK

${ }^{c}$ The University of Manchester, Manchester Academic Health Science Centre, Faculty of Biology, Medicine and Health, Division of Infection, Immunity and Respiratory Medicine, Manchester, UK

d The Adult Burns Centre, University Hospital of South Manchester, Manchester, UK * Corresponding author. Present address: Education \& Research Centre, Wythenshawe Hospital, Southmoor Road, Manchester M23 9LT, UK. Tel.: +44 161 2915941 fax: +441612915806 E-mail address: riina.richardson@manchester.ac.uk (R. Rautemaa-Richardson) 

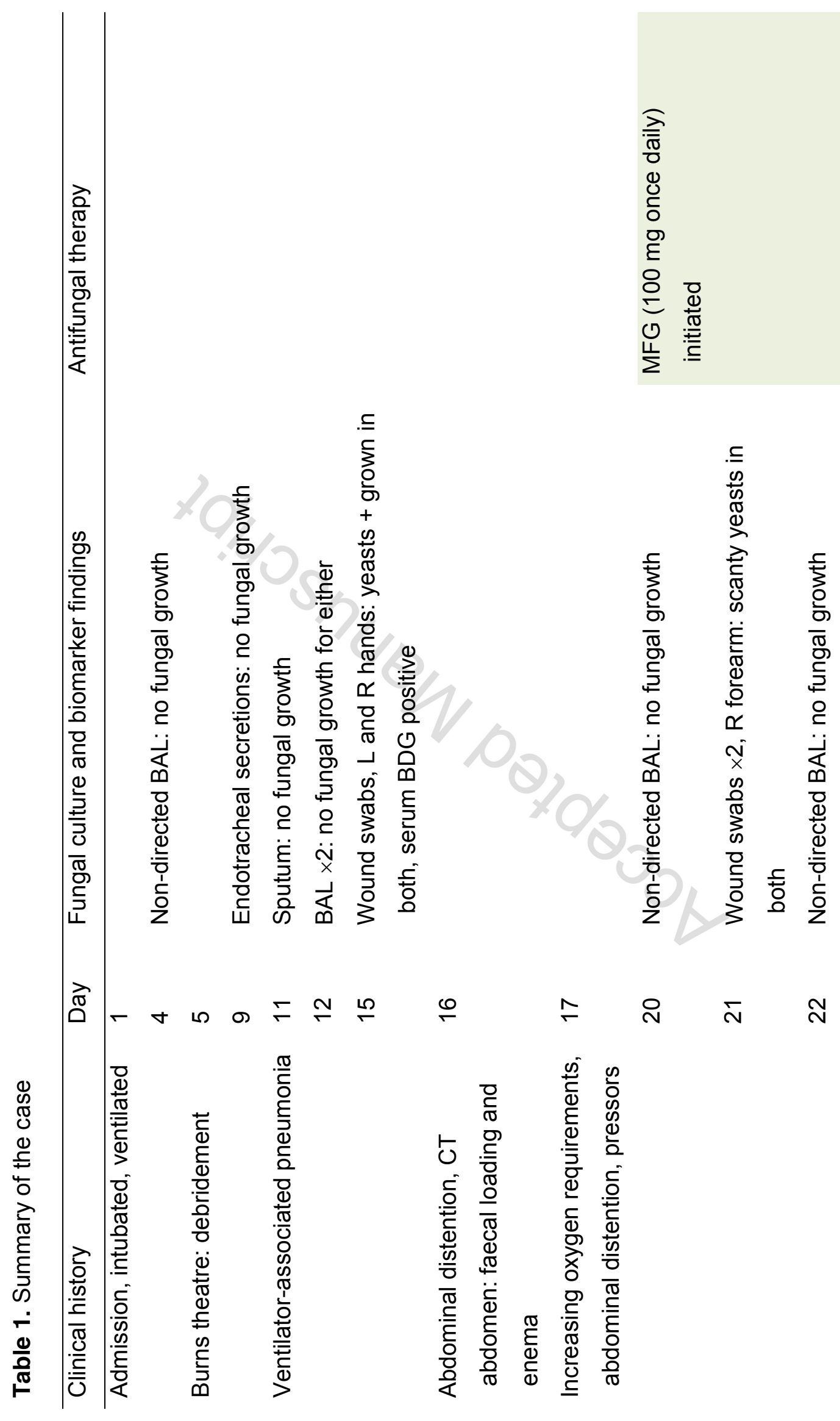

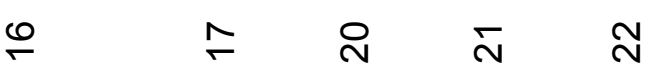

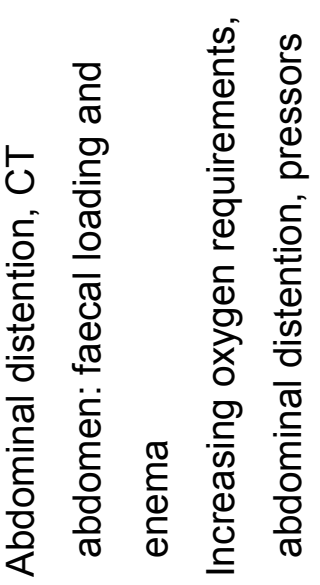



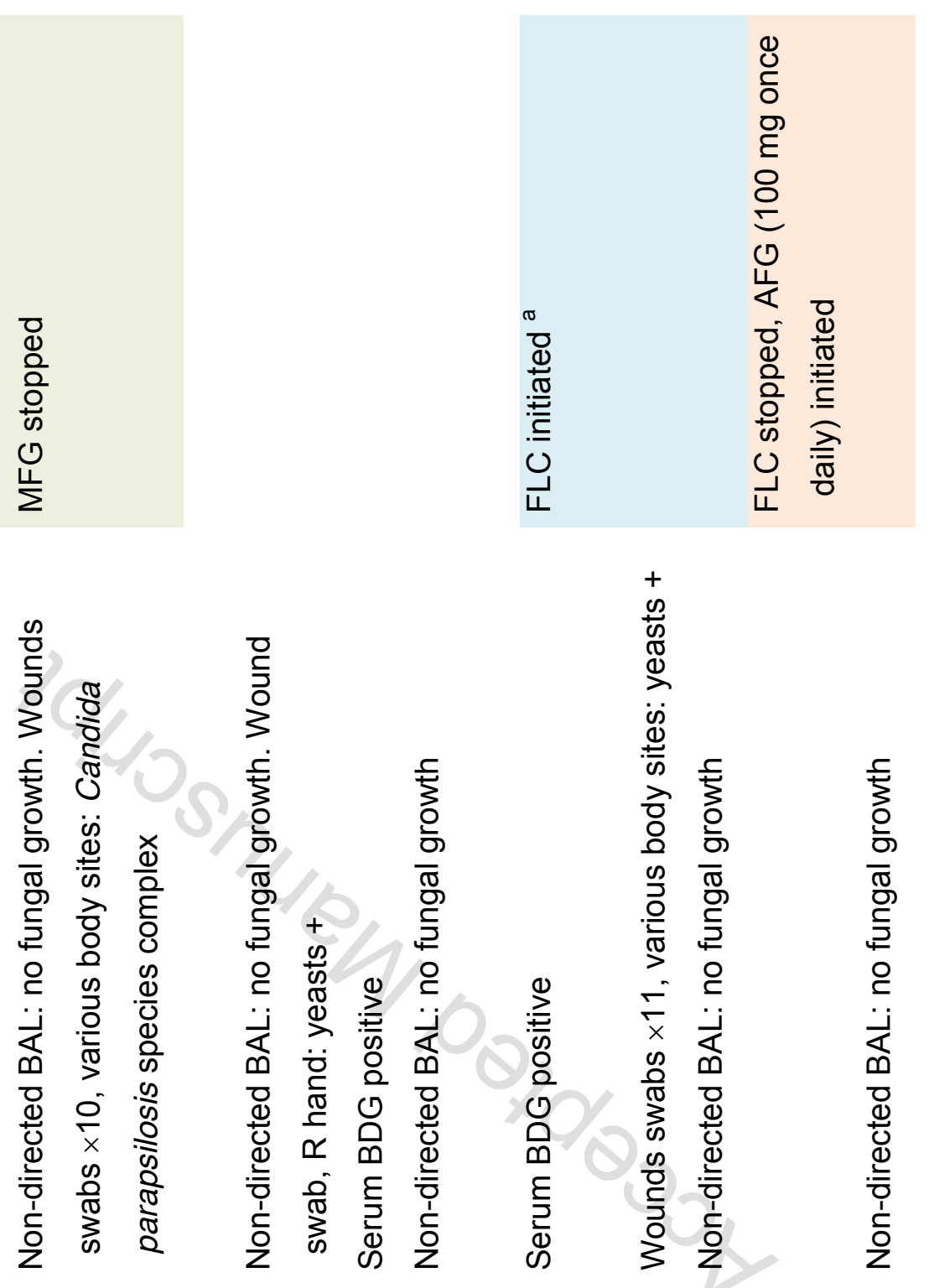

$\stackrel{\sim}{N} \quad$ N

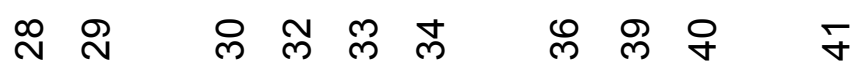
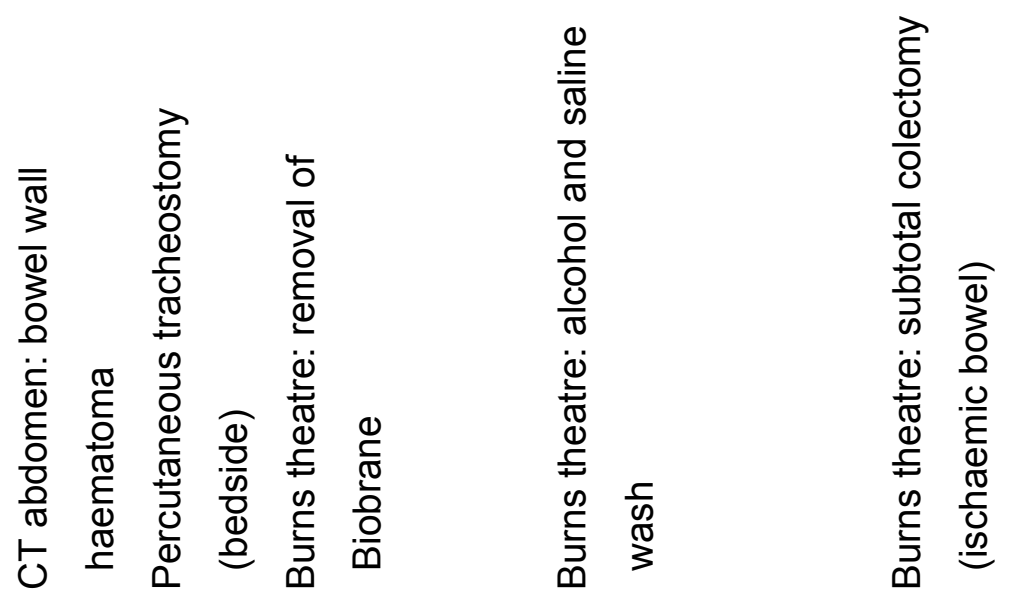


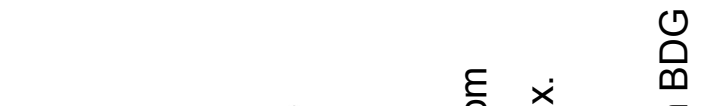
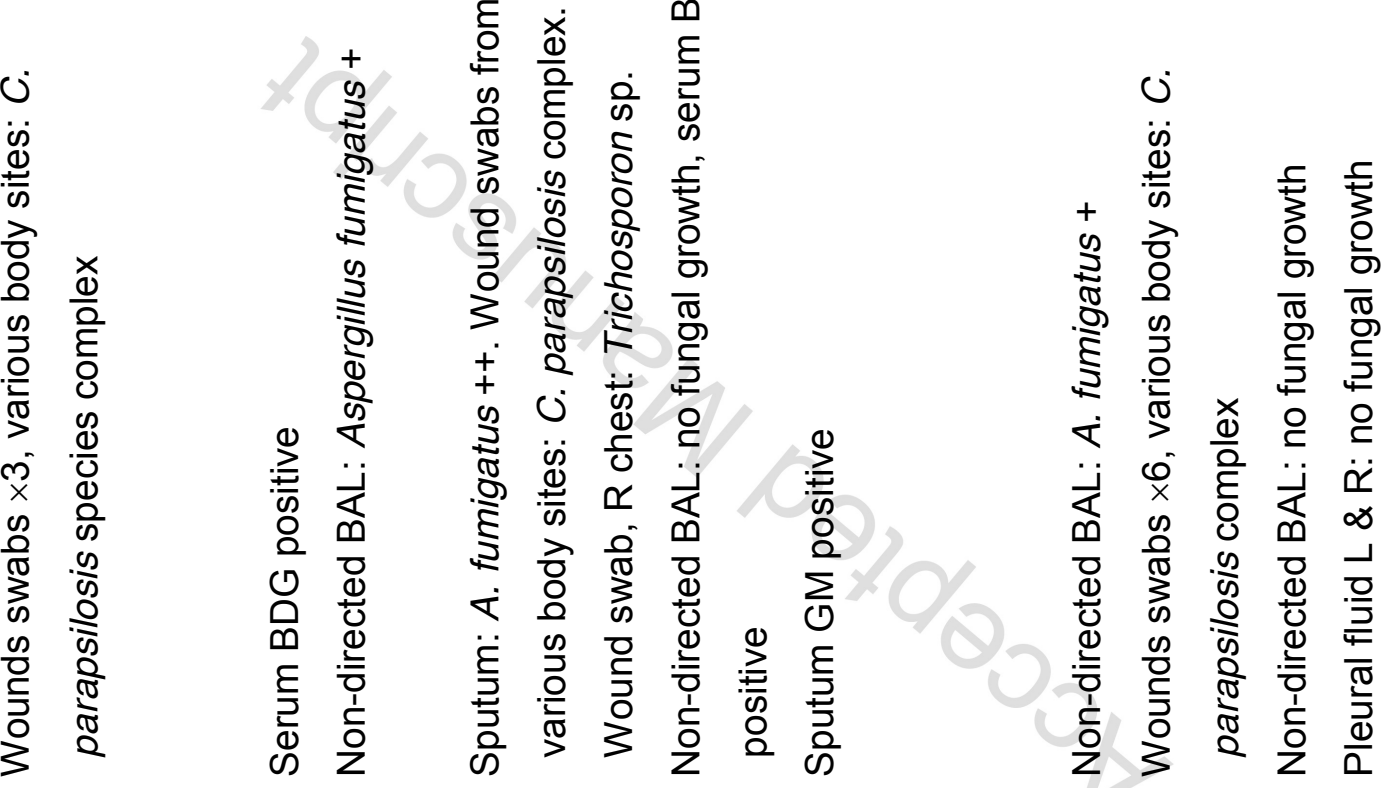

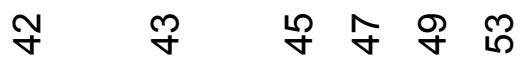

เ

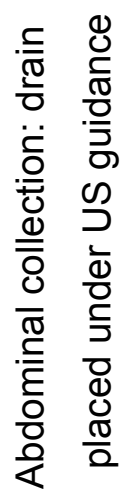

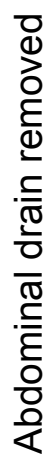

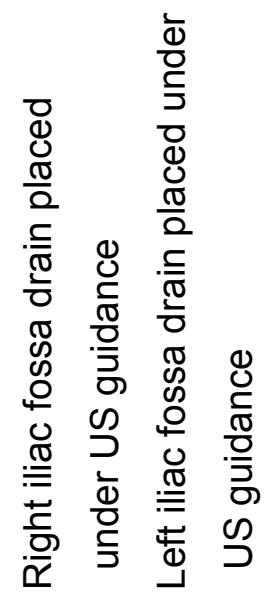



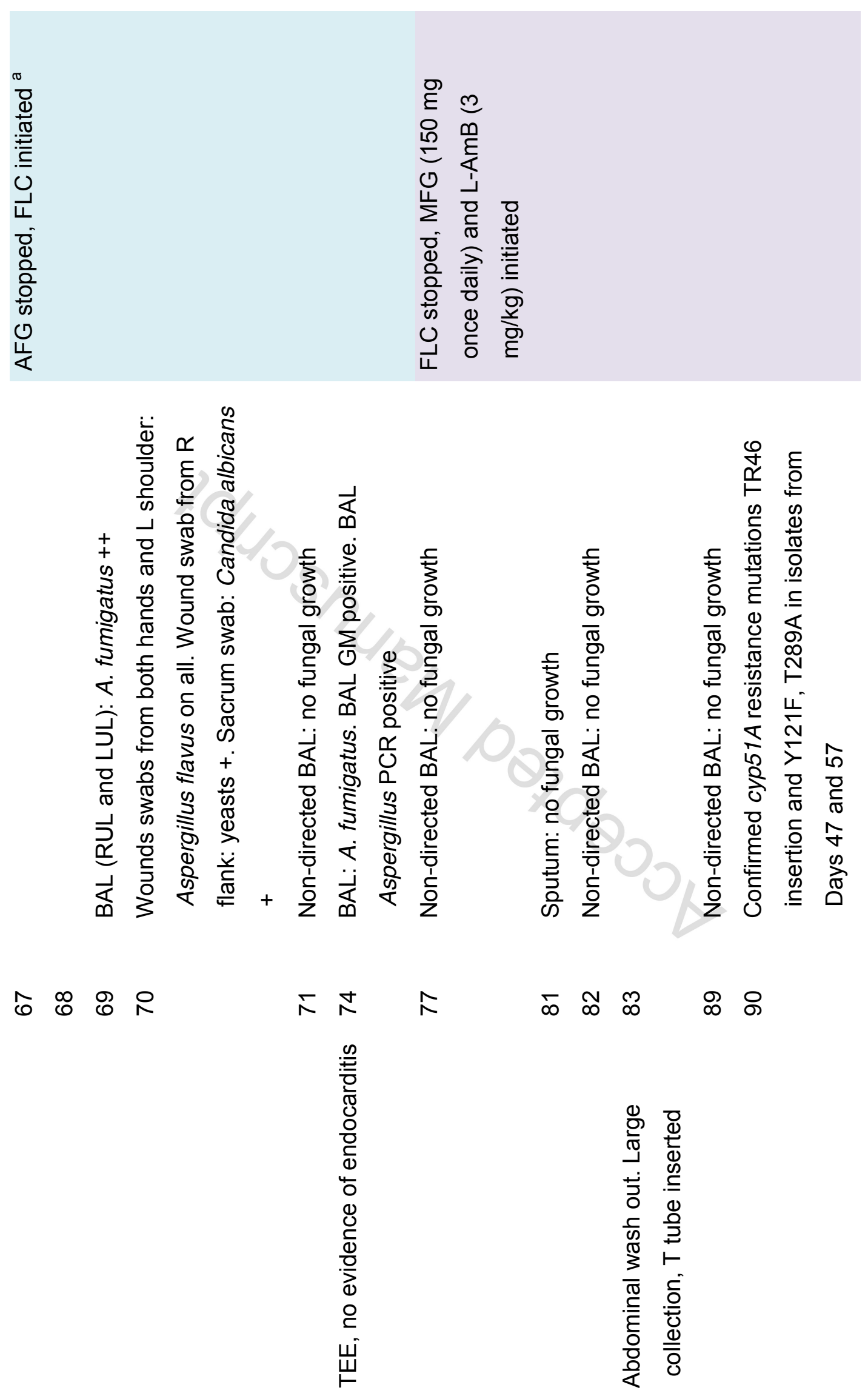


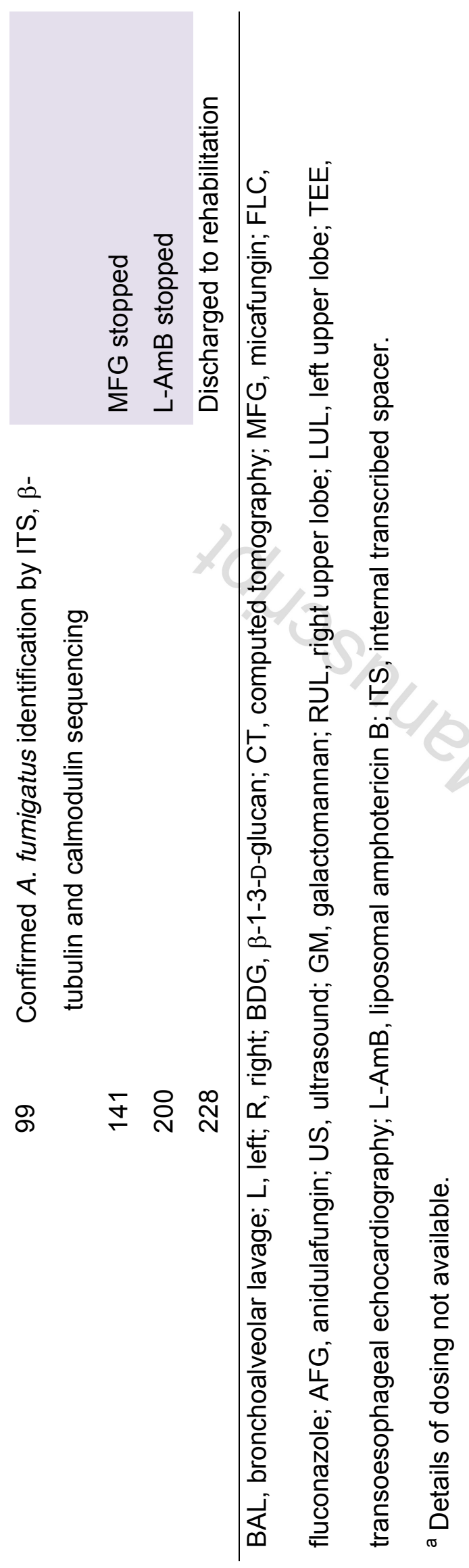

